International Journal of Linguistics, Literature and Culture
Available online at https://sloap.org/journals/index.php/ijllc/
Vol. 4, No. 6, November 2018, pages: 42 52
ISSN: 2455-8028
https://sloap.org/journals/index.php/ijllc/article/view/374

\title{
African Social Appraisals of Women's Liberal and Radical Feminism in Selected Contemporary West and Central African Female and Male Novels
}

\begin{abstract}
CrossMark

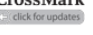

Celestin Gbaguidi ${ }^{\text {a }}$

Akinola Monday Allagbe ${ }^{b}$
\end{abstract}

Article history:

Received: 20 June 2018

Accepted: 30 August 2018

Published: 12 November 2018

\section{Keywords:}

African social appraisals; Contemporary African societies;

Liberal feminism;

Radical feminism;

Women;

\begin{abstract}
Women, particularly in Africa, need feminism so as to advocate for their rights in the patriarchal setting of African societies. But the fact that some women, under the umbrella of it abuse children, men, and even their fellow women are problematic in contemporary African novels. Liberal and radical feminisms are part and parcel of feminisms in championing women's rights. This article examines women's liberal and radical feminist stratagems with the lens of African social appraisals in giving an answer to the following question: what are the African social appraisals of women's liberal and radical feminist stratagems in their quests for women's rights? Or what do the stratagems applied by liberal and radical feminists lead women to in contemporary African societies? Through liberal and radical feminist readings of selected contemporary African male and female writings such as Amma Darko's The Housemaid (1998), Daniel Mengara's Mema (2003), Asare Adei's A Beautiful Daughter (2012), and Lola Shoneyin's The Secret Lives of Baba Segi's Wives (2010), we have examined how women with liberal/radical feminism are treated and considered in African patriarchal setting. In short, the result shows that African women need a feminism that gives way for consistent dialogue and which goes in line with non-violent stratagems like the one of liberal feminism in their quest for women's rights. The contrary, as in radicalism via violence against children, men or women, leads to men's violence on women, isolation of women and humiliation of women in contemporary African societies. The position of the contemporary African female and male novels, we have worked on proves that violent stratagems adopted by African feminists in advocating for women's rights should be reconsidered so as to assure the respect for human rights and take into account the socio-cultural realities of African societies.
\end{abstract}

2455-8028 ${ }^{\circledR}$ Copyright 2018. The Author. This is an open-access article under the CC BY-SA license (https://creativecommons.org/licenses/by-sa/4.0/) All rights reserved.

${ }^{a}$ University of Abomey-Calavi (UAC), Republic of Benin

${ }^{\mathrm{b}}$ University of Abomey-Calavi (UAC), Republic of Benin 


\section{Author correspondence:}

Celestin Gbaguidi,

Doctor of African Literature in English, English Department, University of Abomey-Calavi (UAC),

Republic of Benin

Email address: celestin.gbaguidi@uac.bj

\section{Introduction}

In a recent past, some European and Western scholars gave a distorted image of Africa and Africans as the heart of darkness, uncivilized and lack of customs and traditions. Some even accused Africa and Africans of not having moral codes of conduct. The above views held by the scholars are false. Ogbonmwan (as cited in Olasunkanmi, 2015 , p. 3) argues that "[...] every society has rules, principles, and norms that regulate the conduct of its members." A society or continent without rules, principles, and norms that regulate the conduct of its people is nothing else but a jungle. A jungle is a place where the fittest easily dominate over the weakest. Obviously, in the pre-colonial era, it is argued that the African codes of conduct are not written but the people know how to behave themselves through oral code. In the same vein, Capo-Chichi (2008, p. 32) argues that “[...] malgré l'inexistence de l'écriture, un code oral de savoir-vivre et de savoir être sert de guide [Despite the inexistence of writing, an oral code of know-how to live and know-how to be serves as guide (Translation ours)]." Accordingly, Ifemesia (as quoted in Olasunkanmi, 2015 , p. 3) corroborates that African way of life emphatically centered upon human interest and values; a mode of living evidently characterized by empathy, and by consideration and compassion for human beings. So, the oral code of conduct of how to live and how to behave, the African way of life which values human beings or has compassion for fellow creatures still exists in contemporary African societies. In fact, it applies to any individual be she/he a woman or man with the aim of maintaining good moral and social stability in African societies. Moreover, the oral code of conducts can also serve as measures of social appraisals of any political movements advocating for women's rights like feminism.

Women, particularly in Africa, need feminism so as to advocate for their rights in a patriarchal setting of African societies. But the fact that some women, under the umbrella of it in the quest for women's rights, abuse children, men, and even their fellow women is problematic in contemporary African novels. Liberal and radical feminisms are part and parcel of feminism in championing women's rights. This paper looks into women's liberal and radical feminist stratagems with the lenses of African social appraisals in giving an answer to the following question: what are the African social appraisals of women's liberal and radical feminist stratagems in their quests for women's rights? or what do the stratagems applied by liberal or radical feminists lead women to in contemporary African societies? Through liberal and radical feminist readings of selected contemporary African male and female writings such as Amma Darko's The Housemaid (1998), Daniel Mengara's Mema (2003), Asare Adei's A Beautiful Daughter (2012), and Lola Shoneyin's The Secret Lives of Baba Segi's Wives (2010), we will examine how women with liberal/radical feminism are treated and considered in an African patriarchal setting. Before we examine the novels, we give a brief account of feminism and its branches like liberal and radical feminisms in a theoretical framework.

\section{Materials and Methods}

We have used a qualitative method to conduct this research. Our approach is the post-colonial criticism with the main emphasis on African feminism.

\section{Theoretical Framework}

Feminism is women-oriented and concentrates on issues that concern women. It is a literary movement that tends to bring about a change in the society especially on how women are treated; it tries to discourage discrimination and humiliation on women; it focuses its attention on the emancipation of women (Ann, 2015, p. 427). The central task of feminism is to examine women's oppression and the possibilities for resistance and positive change (Amouzou, 2014, p. 13). Likewise, Koussouhon et al., (2015) argue that "[...] the utmost aim of feminism is to stand up against male-dominance and power as well as free the womenfolk from all forms of societal ills buttressed by patriarchy or systemic institutionalized sexism both in literature and society" (p. 315). However, it is important to point out that

Gbaguidi, C., \& Allagbe, A. M. (2018). African social appraisals of women's liberal and radical feminism in selected contemporary West and Central African female and male novels. International Journal of Linguistics, Literature and Culture, 4(6), 42-52. https://doi.org/10.21744/ijllc.v4n6.374 
feminism carries a lot of connotations even though its aim confronts historical power inequality between men and women in patriarchal African settings as well as in the world. Differences in intellectual and political feminist stratagems of advocating for women's rights, among feminist scholars, have opened the ground for branches of feminism.

It has evolved in eight different areas rather than as one unified concept. The most commonly used are eight separate feminist theories: black feminism, radical feminism, cultural feminism, lesbian feminism, liberal feminism, Marxist feminism, materialist feminism, and socialist feminism (Andermahr, Lovell, \& Wolkowitz, 1997; Evans, 1995 as cited by Kathy and Daley, 2007, p. 51). Among the above branches of feminism, we have based our analysis on two theories which are liberal and radical feminisms in order to examine their suitability with African social appraisals. Although liberal and radical feminisms are common in advocating for women's rights, they are different in stratagems. Samkange (2015) confirms that:

\begin{abstract}
Radical feminism and Liberal feminism are some of the approaches that have been employed to explain inequalities and oppression within societies. These are two opposing approaches in terms of how they advocate for change and reform. The Radical Feminists advocate for revolutionary means to tackle oppression which they believe is a result of the biological differences between men and women. On the other hand, Liberal Feminists advocate for a moderate approach to bringing about change. Such an approach involves the use of legislation and an incremental strategy to bring about change (p. 1172).
\end{abstract}

It appears that liberal feminists believe in equal protection for men and women under the law of a community or nation as a means of promoting mutual respect. They also trust in mediating institutions like patriarchal social institutions. Koukpossi (2016) and Aini (2017) corroborates that these liberal feminists focus on women's ability to work hard to emphasize the equality of men and women through political and legal reforms. It does not seek any opposition between sexes but views the future of women's emancipation through the democratic process including a reorientation of human beings in all culture. In contrast, radical feminists are contrary to liberal feminists in fighting for women's rights because they believe in making judgment themselves and in using violence. Their combative stratagem is sometimes motivated by vengeance as in the following: "If you kill my dog I'll kill your cat" (Nubukpo, 1995 , p. 65). Not only do they crush anybody who serves as the cause of/for their oppressions but they also hold men and patriarchal social structure of their society or societies as responsible for their being violent and violating social norms. They sometimes go beyond patriarchal system which is identified by feminists as "women's main enemy" (Tong, 2009, p. 72) and even see their fellow women who try to oppose them as enemies. In a nutshell, the liberal and radical feminist trends in feminism are typically found in the Western parts of the world. Nevertheless, they are sometimes reflected in some contemporary African literature like Amma Darko's The Housemaid (1998), Daniel Mengara's Mema (2003), Asare Adei's A Beautiful Daughter (2012), and Lola Shoneyin's The Secret Lives of Baba Segi's Wives (2010). With African social appraisals, we have tried to examine women's liberal and radical feminisms in order to underpin the ways women, through the study of the female characters in the west and central African male and female novels, address the problems facing them in the patriarchal setting of the novels and how they are viewed in contemporary African settings.

\title{
3. Results and Discussions
}

\section{African Social Appraisals of Women's Liberal and Radical Feminism in the Female and Male Novels under Study}

In Amma Darko's The Housemaid, the main character is a woman called Sekyiwa/Madam Sekyiwa. She becomes assertive with the help of her husband who invests all his money to open a big shop filled with textile prints for her. That contributes to her wealthy and powerful businesswoman. The above qualities give her empowerment despite her illiteracy in the Ghanaian society. As the narrator informs the reader "[...] Sekyiwa had become one of the wealthy market mummies" (Darko, 1998, p.18). In reality, the success of Madam Sekyiwa in trading confirms what Buchi Emecheta affirms about African women: "Being successful in whatever we undertake is not new to the women of Africa" (1988, p. 180). But unfortunately, Madam Sekyiwa develops a radical feminism against her husband up to the extent that she turns her back from her husband, considering her husband's penis dead and waning away. She pays young good looking male to satisfy her sexually. As the narrator points out: "She gave them good money; they gave her good sex" (Darko, 1998, p. 18).

In fact, through Madam Sekyiwa, Amma Darko, in her struggle for gender equality among men and women, in the Ghanaian contemporary African society, has confirmed Dahlin-Jones' affirmation that "Women are struggling to 
become equals with men in society and according to some radical feminists this means that women should become equally independent, stoic, oppressive and aggressive as the stereotypical male" (2014, p. 10). In a similar vein, as an aggressive act, the female character Sekyiwa insults and beats her husband whenever there is an argument between them. The narrator accounts for the fights and arguments held between them by Tika, their only daughter: "Little Tika remembered the fights and arguments she had witnessed between her parents [...]. She remembered her mother's hands flying at her father's face in time with her insults. It was her father who had wept” (Darko, p. 19). The above act of Sekyiwa is nothing else than feminism, especially radical feminism. On this score, Pewissi (2017) points out "[...] the nature of the concept of feminism offers reasons for resistance" (p. 47). The feminists, especially radical feminists, see the male gender as an oppressing force and believe in using violence as their way of settling problems between both genders. Darko has proved through Sekyiwa's radical feminist attitude to the extent that it leads to the death of her husband. As the narrator informs the reader "Tika returned from school and found the house in tumult. Everyone was wearing black and crying. Her mother called her aside, explained to her what death was, and told her that her father was dead" (Darko, 1998, p. 18). Although Tika is still small when her father passes away, she blames her mother, Sekyiwa, for the death of her father. Or despite the argument Sekyiwa tries to put forward so as to convince her daughter about the death of her father, she does not believe her mother. As the narrator informs the reader through the conversation between Sekyiwa and Tika "Tika wondered her mother had sent him to heaven because she didn't want him anymore. 'Did you make him die?' she asked her mother innocently” (Darko, 1998, p. 19). In fact, as a result of the above, through Tika's doubt of her mother's words concerning the death of her husband, it seems Darko wants to inform the reader that there is no trust among feminist groups.

The accusation of Sekyiwa not only comes from her daughter but she is also accused by her late husband's people who are from the village called Kataso. Indeed, the reaction and judgment of the Katasoans corroborate the reality of a community that binds African societies, particularly the Ghanaian society. Olasunkanmi confirms that "[...] in Africa, no one can stand in isolation, all are a member of a community; to be is to belong. The community gives each person belongingness and cultural identity for self-fulfillment and social security" (2015, p. 5). The communitarian reality of the Ghanaian society especially that of the village of Sekyiwa's husband, serves as a balance to weigh so as to judge if she acts according to African social appraisals, especially to the Ghanaian social Appraisal.

Accordingly, in African societies, particularly in the Ghanaian society, the role played by the people of the village of Sekyiwa's husband confirms that a man/woman's parents serve as Human Right Watch agents in their son's or daughter's marriage. As Ariwoola (1965, p. 16) contends “[...] there are usually around the corners private eyes, at least of those of their parents, taking a keen look at all they [young couples] do". In fact, we think this really should be considered by radical feminist movements in Africa.

In radical feminism, the systematic oppression of women by men is central and the mindset of male superiority is attacked and the liberation of all women is called for. Radical feminists state that the female is the superior sex and a social revolution is needed so that women can gain power in society (Dahlin-Jones, 2014, pp. 5-6). Likewise, as Samkange argues: "The dominance of patriarchy in our perceptions and practices has to be challenged as it makes society accept inequality between men and women as normal. Some element of radicalism may be necessary to change such thinking" (2015, p. 1174). Women may need a radical feminism that does not oppress fellow human beings in the quests for equality, justice, empowerment etc between men and women because human rights are valued in African cultures. As Gyekye (1996, p. 177) notes "[...] the most important values in which human rights are rooted are put into practice in the traditional African cultures. These include individuality, personal responsibility, the dignity and integrity of every person, the intrinsic value of every person, the consideration of every person [...]". The reason why radical feminism may not have its way in African societies is that African cultures and traditions value human beings irrespective of their gender, sex or class. Ifemesia (as cited in Olasunkanmi, 2015, p. 3) contends that "African way of life emphatically centered upon human interest and values; a mode of living evidently characterized by empathy, and by consideration and compassion for human beings". In addition, Gyekye (1996, p. 36) argues that "Members of a communist society are expected to demonstrate a concern for the well-being of others ..." But the other way round where women's radical feminism is based on provocative violence on one's fellow by hiding under the umbrella of equality, justice, empowerment etc., between women and men is not forgiven in contemporary African societies, especially in the contemporary African Ghanaian society. This is shown in Tika's rigidity against her mother for the death of her father. Although Sekyiwa tries to buy her forgiveness by signing a big check for her so as to establish her own business as a wholesaler, she does not forgive her mother for that. As the narrator confirms "She could not buy Tika's forgiveness. It would have to come from Tika herself" (Darko, 1998, p. 36). Although Tika collects the check her mother has signed to buy her forgiveness,

Gbaguidi, C., \& Allagbe, A. M. (2018). African social appraisals of women's liberal and radical feminism in selected contemporary West and Central African female and male novels. International Journal of Linguistics, Literature and Culture, 4(6), 42-52. https://doi.org/10.21744/ijllc.v4n6.374 
she blames her mother for all her plights even after the death of her father. That is, she accuses her mother of being responsible for the troubles she encounters before and after the death of her father. The accusation Tika holds against her mother makes her turn down her warning not to terminate a pregnancy she has for one of her lovers called Attui who has many wives: "I [Tika] won't keep this pregnancy, mother. It will make me do to Attui's wives what you did to father's first wife [...]. She ended the pregnancy" (Darko, 1998, p. 27). Through the above quotation of her resistance against her mother, it is confirmed that apart from the problem of barrenness that makes Sekyiwa's husband divorce his first wife, Sekyiwa is another cause for their divorce. In addition, Sekyiwa's lust for the man's riches can make her give in to him even if she knows he is married. Adeyemi and Ajibade (2009, p. 110) argue "women's lust for money and material wealth is the highest in rank when it comes to causes of women's weakness". Although Sekyiwa becomes a wealthy market mummy, her radical feminist ideology makes her only daughter not see her as a feminist model to follow. The feminists, especially radical, encourage "[...] a rhetoric of exclusion that promises salvation for women alone" (Nubukpo, 1995, p. 59). The above feminists' standpoints sometimes make some women radically exercise violence on their male counterpart. But something that radical feminist women ignore is that a man belongs to a family, he is not alone. As Olasunkanmi $(2015$, p. 8) stipulates "There is nothing like individualism in Africa, a man in Africa is not alone, he belongs to a family and he represents that family where ever he or she goes." As a result, Sekyiwa is not forgiven by the people of her late husband. They have shown this when Tika has to get a housemaid to help her at home. She is informed of the anger of the Katasoans by Teacher, a woman who is an aborigine of Kataso like Tika's late father: "I [Teacher] don't think anyone in Kataso would want a daughter of theirs to come to serve and live with your mother. No matter how desperately they would want the opportunity for their daughter to escape from the village, it would stain that family. They would always have to live with the guilt and shame of having given in to an enemy" (Darko, 1998, p. 36). The above argument from Teacher reveals that Sekyiwa is considered as an enemy of the Katasoans. In this sense, Darko is informing the reader that radical feminist women who do not respect the socio-cultural realities of their societies, especially African societies, are considered as enemies. One of the socio-cultural realities of African societies, especially the Ghanaian society, is valuing human life and forming a community of brothers and sisters despite the problems and differences among the female and male genders. Biko (as quoted in Olasunkanmi, 2015, p. 5) stipulates that we [Africans] regard our living together not as an unfortunate mishap warranting endless competition among us but as a deliberate act of God to make us a community of brothers and sisters jointly involved in the quest for a composite answer to the varied problems of life.

Hence in all, we do we always place man first and hence all our action is usually a joint community-oriented action rather than individualism. So, most women who are radical feminists live in isolation in contemporary African societies, especially contemporary African Ghanaian society because they are deserted by their beloved ones. In reality, this is shown in Amma Darko's novel through Sekyiwa who is abandoned by her only daughter, Tika. As the reader is informed "Since the day she had come home to find Tika gone, Sekyiwa had been living in a daze [...]. And she locked herself up in her house" (Darko, 1998, p. 38). In short, the story of Sekyiwa ends where her daughter, Tika, is admitted to hospital after aborting the pregnancy she has for Attui. A male nurse comes and informs her but she is not happy when she asks the nurse to see if Tika has sent him and he says no. She is discouraged. As the reader is informed through the male nurse "He could still hear Sekyiwa mumbling to herself as he walks away" (p. 39). Though Sekyiwa, as a radical feminist, succeeds in life but ends up in isolation, Darko has tried to inform her readers, particularly women on the consequences awaiting radical women in African societies, especially in the Ghanaian society. Concerning Tika, her ways of behaving and countering Sekyiwa for the death of her father qualify her as a liberal feminist woman. As Dahlin-Jones (2014, p. 7) argues "[...] liberal feminists choose to see people as individuals and work for gender equality through political reform. Men and women are different, but these differences need to be celebrated and appreciated equally and women do not have to turn into men or be adverse towards men, in order to attain an equal status in society". In fact, Tika's liberal feminist ideology makes the Katasoans, the aborigines of Tika's late father, have nothing against her. Although Tika lives a promiscuous life with different men in her course to sustain her business, the Katasoans give her the housemaid she requests from them. As the reader can deduce in the following Tika is assuring the parents of the housemaid named Efia of her intention for her as her housemaid: "I will take complete care of her. I will not maltreat her. After four years, I will enroll her as an apprentice seamstress. And before we part ways she will have her own sewing machine, plus ample money to get started in life" (Darko, 1998, pp. 41-42).

Just like Sekyiwa in Amma Darko's novel, in Asare Adei's A Beautiful Daughter, there is the case of Mansa. She becomes a radical feminist because of gender injustice against women with illegitimate children or divorced women 
with children in the Ghanaian society. Indeed, she encounters the difficult situations those women face when she wants to get married. That is because she has got a child called Kojo for a man named Asamoah who refuses to marry her. She is obliged to hide the child she has got in her previous relationship in order to get married to another man called Sam. With her feminist charisma, she succeeds in making Sam adopt her son, Kojo Asamoah. The son later bears the family name of her new husband, Kojo Sam Quaye. "[...] after the formalities for the adoption of the boy was over [...] Sam then moved closer to the boy and asked, 'What's your name, again?' 'Kojo Asamoah,' the boy replied, and then he looked up at Sam. 'I see. Hence forth, you are Kojo Sam Quaye Junior, [...] 'I'm now legally your father. I'm going to take good care of you, okay?” (Adei, 2012, p. 60) But Mansa's radical feminist ideology makes her exercise child abuse on Sam's daughter. As clarity, a child abuse is when a parent or caregiver, whether through action or failure to act, causes injury, death, emotional harm or risk of serious harm to a child. There are many forms of child maltreatment including neglect, physical abuse, sexual abuse, exploitation, and emotional or psychological abuse. It is observed from Mansa to Baaba, Sam's daughter, with her intention of destroying her. For example, Mansa uses emotional or psychological abuse. She denigrates of her personality before her father to the extent of making her father exercise physical abuse on her: "She broke the glass because I called her my daughter! You see some of the things your daughter is capable of?" (Adei, 2012, p. 68) Sam's violent reaction on his daughter is due to Mansa's denigration of her in front of him: "Sam walked angrily into the kitchen and sent a slap across his daughter's face. 'What sort of behaviour is that? You dropped the glass because she called you her daughter. The insolence! It has to stop now, is that right?' he yelled" (Adei, 2012, p. 68). It is the duty of parents to correct their children when they find them insolent to elderly person but the fact that the correction of child/children is provoked by a parent or caregiver is problematic. In this wake, Gyekye (1996, pp. 75-76) argues that "Children have obligations to their parents and parents have obligations to their children."

Another aspect of child abuse used by Mansa against Baaba is neglect. Kendall-Tackett (2001, p. 3) argues that "Neglect is by far the most common type of child maltreatment. Unlike physical or sexual abuse, where something is actually done, neglect is the failure to do something [...]. It can include failure to supervise, provide a safe environment or provide proper education." As a matter of fact, Mansa's parental neglect of Baaba makes her have unwanted pregnancy for Okai at the age of sixteen. That has made Sam chase his daughter away after discovering that she is pregnant for Nii Okai. But when Sam discovers that Mansa is maltreating his daughter, he becomes angry with her. That gives birth to men's violence from Sam to Mansa in the novel: "She can't live here and maltreat my daughter, no way!' Sam shouted, withdrew his hand, whirled and stone-faced, delivered a kick to Mansa's ribs, kung-fu-style. 'Nobody humiliates my daughter...nobody...not even my wife!' he declared" (Adei, 2012, p. 50). Although many human right advocates have condemned violence against women, Adei has tried to inform the reader that the violence against women may surely increase if women continue ill-treating or abusing children in the name of equality, empowerment, justice etc. it appears that child abuse is a product of radical feminists. Women who practice radical feminism in contemporary African societies, especially in contemporary Ghanaian society, are qualified as witches even by their fellow women. As one can realize in the following statement by Pokua, Baaba's maternal auntie: "She's your wife and now that the witch [Mansa] has gone..." (Adei, 2012, p. 78). In addition, those women are believed to back up all their actions by supernatural power. The above belief can be inferred as follows: "I know why you're acting this way. It's juju [African magic power]. For all know, Mansa is standing somewhere on the demonic rock of Patakro, reciting incantations.' Pokua pursed her lips. 'Patakro women are noted for that if you don't know" (Adei, 2012, p. 60). Finally, radical feminist women live in solitude at the end of their lives because they are ignored and this makes them feel shameful of themselves. It is the case of Mansa when Sam discovers her secrets and how she ill-treats his daughter. He decides to park out her belongings. But she finds it unbearable to go and live somewhere else and she occupies a guest house built by him. The narrator informs the reader that "After a careful thought, he decided he would just ignore her" (Adei, 2012, p. 135).

Unlike Mansa with radical feminism, Esi, another female character in Adei's novel, considers the culture and tradition of her people, in her struggle against her husband's, an unjust manner towards her. She is different from Mansa because she applies liberal feminist ideology in her struggle. Contrary to Mansa, who uses violence against her husband's daughter in her quest for justice and equality for women, Esi has used dialogue and traditional institutions to make her plight known and solved. Esi's stratagem fits in with Mary Holmes' argument that "liberal feminism [...] seems to assume that women have to fit into the present system, rather than that system changing" (2007, p. 73). Through the Ghanaian traditional institutions which the narrator represents with Aboadze, she contests against the custom that makes a senior wife lose her seniority to a junior wife if she happens to park out her loadout from her husband's house without being chased away by her husband himself. She totally refuses to come and lives in a guest house while the new wife, Mansa, lives in the main building during the meeting held for her reconciliation

Gbaguidi, C., \& Allagbe, A. M. (2018). African social appraisals of women's liberal and radical feminism in selected contemporary West and Central African female and male novels. International Journal of Linguistics, Literature and Culture, 4(6), 42-52. https://doi.org/10.21744/ijllc.v4n6.374 
with her husband before her parents and those of her husbands' in front of the elders of Aboadze. The narrator informs the reader of her pacific resistance in the followings: "If you will, but I'm not going with him into that house,' Esi insisted" (Adei, 2012, p. 42). The above attitude of Esi defies the stereotypical roles attributed to women in pioneering male novels. Likewise, she sticks to her position even when her husband proposes to rent an apartment for her. She answers her husband in the followings: "Why not a rented apartment for her, but for me? Look, I'm not with you ... not now, nor tomorrow, nor the day after. Do what you came to do and, when you're through, safe journey back home to your wife.' Esi left the meeting in tears" (Adei, 2012, p. 42). Through the above radical attitude to the proposition of her husband, Adei has the reader imagine that she is a rebel to the custom of the people of Aboadze that her parents and those of her husband's parents represent. Her attitude may be considered as a rebel because elderly people, as well as parents, are respected in African societies, especially in the Ghanaian society. Indeed, in Africa old age is honored, celebrated and respected. The respect given to the elders has its practical effect in the maintenance of custom and tradition (Olasunkanmi, 2015, p. 6). But her action (Esi's action) somehow confirms Samkange's argument that "The dominance of patriarchy in our perceptions and practices has to be challenged as it makes society accept inequality between men and women as normal. Some elements of radicalism may be necessary to change such thinking" (2015, p. 1174). Nevertheless, her un-harmful radicalism obliges the traditional institution represented by the elders of Aboadze to know that women have the right to have a say regarding the problem facing them in contemporary African societies, especially contemporary African Ghanaian society. In a nutshell, two wrongs cannot make one right, says a common adage. Adei, in his struggle to bring his stone to the edifice of the womanist and radical feminist struggle for women's rights, justice and reconstitution of the distorted images of women in contemporary Ghanaian society, has tried to call the attention of women on the fact that an evil cannot be corrected with an evil through his portrayal of Mansa. He recognizes that it is difficult for women as womanists or feminists to have an immediate change of an institution like patriarchy which has got its foundation in many traditional practices thousands of years back. But with patience and consistent dialogue, he has been able to prove through Esi who is portrayed as a liberal feminist that feminists can win their battle for equal rights and justice for women as men in contemporary patriarchal settings of Africa, especially in contemporary Ghanaian society if they use dialogue and try to value the positive things in the existing institutions in African patriarchal societies. In this vein, Esi succeeds in recovering her position as the first wife of Sam: "Esi should feel pleased to share the main building with him [Sam] while her rival [Mansa] made do with the guest house" (Adei, 2012, p. 135). So, social appraisals of Africans should be considered by radical feminists in their advocacy for women's rights. In the next part, we try to examine the social appraisal of women's liberal or radical feminism in Daniel Mengara's Mema.

Indeed, in this novel, the main female character is Mema and also called Ntsame Minlame. Mema like other female characters portrayed in Mengara's novel are liberal feminists but oppressions coming from the menfolk make them develop radical feminism so as to advocate for their rights. Notably, in African societies, especially in the Gabonese society, a woman is not only expected to be submissive to her husband and pay attention to the taboos of her husband's people when she is married but she is also expected to do the same to her in-laws. When the married wife does not want to conform to the above principles she is confronted by her in-laws. For instance, Mema is portrayed as strong and assertive. Her husband is sick and she has tried modern medicine and religion on the problem of her husband but she cannot find satisfaction. Thereafter, she decides to take him to a traditional therapist. That decision is countered by her in-laws. It has brought confrontation between her and the in-laws, on the one hand. It has also made her radical, on the other hand. She is confronted by Akoure Okang, one of her sisters-in-law, when she opposes to her warning of not to take her sick husband to the therapist so as to have a cure. The above radical decision taken by Mema in opposition to her in-laws brings about conflicts between them: "[...] when Akoure heard that my mother had taken her brother to the mimbiri [witchdoctor], she went crazy. She not only rallied to her crusade those among her own sisters who are married away, but also came back to our village, which was her native village, to rally her other village sisters" (Mengara, 2003, p. 39). It is noteworthy that African women play pertinent roles in appreciating social appraisals of their fellow women and maintaining social norms in contemporary African societies, especially in the Gabonese society. For instance, in the novel, Akoure, in her course to make Mema abide by the customary rules of her husband's people, succeeds in gathering "A troop of thirty women went in the war against my mother. And here they were, marching towards the camp like an army of invaders, ready to strike. People knew these women had come for battle because they all wore pieces of cloth tightly secured around their waists. The bottoms of their dresses were also secured to prevent accidental viewing of what was underneath" (pp.39-40). The above attack of Mema by her sisters-in-law shows that women who are rebellious to status quos defined by the traditional patriarchal setting of Africa are sometimes feared. They are sometimes confronted with 
emotional/psychological abuse. According to Khan (2000, p. 2) Psychological abuse which includes behaviour that is intended to intimidate and persecute, and takes the form of threats of abandonment or abuse, confinement to the home, surveillance, threats to take away custody of the children, destruction of objects, isolation, verbal aggression and constant humiliation. As psychological abuse, Mema is denigrated by her sisters-in-law of Mema. She is called names by her sisters-in-law as the destroyer of the village, the terror of all in the village and beyond: "[...] Ntsame Minlame, the woman who had become the terror of all in the village and beyond. Did her name, which meant 'destroyer of villages', not tell it all? Ntsame Minlame had come to our village to destroy it” (Mengara, 2003, p. 42). In fact, women with radical characters like Mema in the above are called names such as crazy women and witches: "Ntsame Minlame, crazy woman, witch! You do not have any respect for anyone" (Italics ours) (p. 48). The reason for Mema's radicalism is somehow justified. It is found in the provocative attitude of her sister-in-law, Akoure and other members of her husband's family towards her. "I [Mema] have had enough of you [Akoure] and your family beat me up with your vipers' tongues. I have had enough of your people treating me like goat-shit. You have called me a sorceress, you have accused me of being a witch. I say to all of you today that if you do not leave this place at once, you are going to see the real witch in me. If you do not leave me in peace, blood is going to flow. Otherwise, you can take my name away from me" (p. 48). In a nutshell, the majority of the female characters as in women/wives in Mengara's novel adopt liberal feminism at the beginning of the novel but the persistence of injustice against them from the menfolk against them makes them change their position. The narrator has revealed through Mema how a woman with liberal feminism concept can sometimes become a radical feminist.

It is the case of Iya Segi, the first wife of Baba Segi in Lola Shoneyin's The Secret Lives of Baba Segi's Wives. She starts as a liberal feminist but later changes to radical feminist due to jealousy, pride, and envy. The narrator informs the reader the discussion between Iya Segi, the first wife and Iya Femi, the third wife: "Don't you see her highbrow and unconcerned eyes? She thinks we are beneath her. She wants our husband to cast us aside as the illiterate ones [...]. As a wife who has recently joined our household, it is her duty to submit to our wishes, not to think she can teach us" (Shoneyin, 2010, p. 52). The fact that she fears Bolanle, the fourth wife will reveal her secrets and those of the other two wives on the day their husband takes to her to the hospital so as to understand the reason why she is not able to be pregnant like his other wives. She knows her husband is sterile and she has got her children with his driver. She has advised the second and third wives not to count on their husband if they want to have children. The fear of their husband knowing the secrets through Bolanle makes Iya Segi become a radical feminist. That has made her attempt to destroy the fourth wife by radical means. Not only does she maltreat the fourth wife physically but she has also complotted with Iya Femi, the third wife, to destroy her. Iya Segi and Iya Femi attempt to poison Bolanle, the fourth. Their radicalism has led to premature the death of Segi, the daughter of the first wife who eats the poisoned food prepared for the fourth wife. Women who are radical are not without sanction due to social appraisals of individuals in African societies. Iya Segi and Iya Femi are obliged by their husband to shut down all their economic activities and render their money to him. They later change to liberal feminists by not challenging the belief that a woman has to be submissive to her husband. They have obeyed their husband in order to save their household and secrets from shame. They lose their power and assertiveness because they do not want to live in isolation. Apart from Bolanle who decides to leave the marital home, all the other three wives are banned from leaving the house without the permission of their husband. The husband promises to buy the three wives all that they need such as jewelry, clothes etc. under the condition that they would wear them within the four walls of their home.

\section{Conclusion}

In this paper we have shown that women, particularly in Africa, need feminism so as to advocate for their rights in patriarchal setting of African societies but the fact that some women, under the umbrella of it, in quest for women's rights, abuse children, men, and even their fellow women is problematic in contemporary African societies. However, contemporary African male and female writings such as Amma Darko's The Housemaid (1998), Daniel Mengara's Mema (2003), Asare Adei's A Beautiful Daughter (2012), and Lola Shoneyin's The Secret Lives of Baba Segi's Wives (2010), have played the roles of mouthpiece of Africans on the stratagems of feminism by denouncing inhuman radicalism in feminist movements in their quest for women's rights in African societies. In this vein, they shed light on African's social appraisals of women with radical/liberal feminism in contemporary African societies through different representations of the female characters in contemporary African societies as in liberal and radical feminism. In short, through the analysis carried out on the African male and female novels, we have come up with

Gbaguidi, C., \& Allagbe, A. M. (2018). African social appraisals of women's liberal and radical feminism in selected contemporary West and Central African female and male novels. International Journal of Linguistics, Literature and Culture, 4(6), 42-52. https://doi.org/10.21744/ijllc.v4n6.374 
the result that shows that African women need a feminism that gives way for a consistent dialogue and non-violent stratagems like the one of liberal feminism in their quest for women's rights. But the contrary, as in feminist radicalism via violence against children, men or women, leads to men's violation of women, isolation of women and humiliation of women in contemporary African societies because it trespasses the socio-cultural moral values of Africans. So, the position of the contemporary African female and male novels, we have worked on, proves that violent stratagems adopted by African feminists in advocating for women's rights should be reconsidered so as to assure the respect for human rights and take into account the socio-cultural realities of African societies.

Conflict of interest statement and funding sources

The authors declared that they have no competing interest. The study was financed by personal funding.

\section{Statement of authorship}

The authors have a responsibility for the conception and design of the study. The authors have approved the final article.

Acknowledgments

The authors thank the Department of English of the University for their support of the publication of this paper 


\section{References}

Adei, A. (2012). A beautiful daughter. Ghana: Asdan Vision Books.

Adeyemi, L., \& Ajibade, M. I. (2009). Portrayal of Women Characters in Selected Contemporary Yoruba Novels in Nigeria. African Research Review, 3(3).

Aini, Z. (2017). The Actualization of cultural elements in novel Guru Onyeh by Salman Faris. International Journal of Social Sciences and Humanities (IJSSH), 1(3), 17-27.

Akoété, A. M. O. U. Z. O. U. (2014). Ideological Ambiguities and Social Relevance in Buchi Emecheta's The Slave Girl. Littérature, Langues et Linguistique, 2(2).

Ariwoola, O. (1965). The African Wife. O. Ariwoola.

Bell, H. (2000). Feminism Is for Everybody: Passionate Politics.

Capo-Chichi, L. C., \& Agboadannon, K. A. D. The phenomenon of street children in Amma Darko's Faceless.

Dahlin-Jones, A. (2014). The Radical Feminists' Misrepresentation of Catherine Barkley in Ernest Hemingway's A Farewell to Arms.

Darko, A. (1998). The Housemaid. Heinemann.

Gyekye, K. (1996). African cultural values: An introduction. Sankofa Publishing Company.

Holmes, M. (2007). What is gender?: Sociological approaches. Sage.

Ibeku, I.A. (2015). "Adichie's Purple hibiscus and the issue of feminism in African novels," Journal of Literature and Art Studies, 5, No. 6, June, pp. 426-437.

Kendall-Tackett, K. A. (2001). The hidden feelings of motherhood: Coping with stress, depression, and burnout. New Harbinger Publications.

Khan, M. (2000). Domestic violence against women and girls. Innocenti Digest, 6.

Koukpossi, A. (2016). "Stylistic analysis of Chimamanda Ngozi Adichie's Purple hibiscus and Sefi Atta's Everything good will come: A systemic functional linguistics perspective," An unpublished dissertation of University of Abomey-Calavi submitted for Doctor of Philosophy, Benin Republic.

Koussouhon, A. L., Akogbeto, P. A., \& Allagbe, A. A. (2015). Portrayal of Male Characters by a Contemporary Female Writer: A Feminist Linguistic Perspective. International Journal of Advanced Research, 3(12), 314-322.

Lay, K., \& Daley, J. G. (2007). A critique of feminist theory. Advances in Social Work, 8(1), 49-61.

Mengara, D. M. (2003). Mema. Heinemann.

Nubukpo, K. M. Men's power and the rhetoric of black women's Visibility in Toni Morrison's Tar Baby. Sciences Sociales et Humaines, 8-13.

Olasunkanmi, A. (2015). A Philosophical Appraisal of Basic Cultural Values in African Tradition. International Journal of Politics and Good Governance, 6(2), 1-12.

Petersen, K. H., \& Wästberg, P. (1988). Criticism and Ideology: Second African Writers' Conference, Stockholm, 1986 (Vol. 20). Nordic Africa Inst.

Pewissi, A. (2017). Rethinking womanism: When difference maps chaos, Accra-North, Ghana: Yamens.

Samkange, W. (2015). The liberal feminist theory: Assessing its applicability to education in general and early childhood development (ECD) in particular within the Zimbabwean context. Global Journal Advanced Research, 2, 1172-1178.

Shoneyin, L. (2010). The Secret Lives of Baba Segi's Wives. Profile Books.

Tong, R. (2009). Feminist Thought: A More Comprehensive Introduction Colorado.

Gbaguidi, C., \& Allagbe, A. M. (2018). African social appraisals of women's liberal and radical feminism in selected contemporary West and Central African female and male novels. International Journal of Linguistics, Literature and Culture, 4(6), 42-52. https://doi.org/10.21744/ijllc.v4n6.374 


\section{Biography of Authors}

\begin{tabular}{|l|l||}
\hline \hline 5 & $\begin{array}{l}\text { Dr. Célestin Gbaguidi is a senior Lecturer of Anglophone African Literature at } \\
\text { Abomey-Calavi University in Benin. He holds a Doctorate degree in Anglophone } \\
\text { African Literature from the same University. His research interests are mainly gender } \\
\text { issues, good governance in the political arena, and youth migration in literature. } \\
\text { Email: celestin.gbaguidi@uac.bj }\end{array}$ \\
\hline & $\begin{array}{l}\text { Mr. Akinola Monday Allagbe is a doctoral student in Anglophone African Literature, } \\
\text { at the Graduate School of the Faculty of Arts and Social Sciences at Abomey-Calavi } \\
\text { University ithe n Benin Republic. He holds a post-graduate diploma (DEA) in } \\
\text { Anglophone African Literature from the same University. He is currently conducting } \\
\text { his research on African feminism. } \\
\text { Email: akinolas4u@yahoo.fr }\end{array}$ \\
\hline
\end{tabular}

